\title{
Residual mechanical properties of calcareous and granite aggregate concretes after fire
}

Cristina Calmeiro dos Santos

Professor, Institute for Sustainability and Innovation in Structural Engineering (ISISE), Polytechnic Institute of Castelo Branco, Castelo Branco, Portugal

\section{João Paulo C. Rodrigues}

Professor, Institute for Sustainability and Innovation in Structural Engineering (ISISE), University of Coimbra, Coimbra, Portugal

The residual mechanical properties of concrete after a fire depend on the high temperatures to which the material was subjected and the nature of the fire extinguishing process used. Knowledge of these properties is of the utmost importance in an evaluation of the residual load-bearing capacity of reinforced concrete elements and their repair after fire. This paper presents the results of an assessment of the residual mechanical properties of ordinary concrete after fire. Concretes comprising granite and calcareous aggregates were studied as they are commonly used around the world in civil engineering construction. The study considered different loading levels $\left(0 \cdot 3 f_{c d}\right.$ and $\left.0 \cdot 7 f_{c d}\right)$, different cooling processes (cooling in air and by water jet) and varying maximum temperatures of concrete exposure (20, 300, 500 and $700^{\circ} \mathrm{C}$ ). The mechanical properties of the concretes (residual compressive strength, direct and splitting tensile and flexural strengths and modulus of elasticity) after being subjected to high temperatures were studied. High temperatures and sudden cooling of the concrete showed a negative effect on its residual mechanical properties. This effect was more significant for the residual compressive strength than for the other mechanical properties.

\author{
Notation \\ d diameter \\ $\bar{E}_{c} \quad$ mean value of modulus of elasticity at ambient \\ temperature \\ $\bar{E}_{\mathrm{c} T} \quad$ mean value of residual modulus of elasticity of the \\ concrete after being subjected to temperature $T$ \\ $f_{\mathrm{c}} \quad$ compressive strength of the concrete at ambient \\ temperature \\ $\bar{f}_{\mathrm{c}} \quad$ mean value of compressive strength of the concrete at \\ ambient temperature \\ $f_{\text {cd }} \quad$ design value of compressive strength of the concrete at \\ ambient temperature \\ $f_{\mathrm{c} T} \quad$ residual compressive strength of the concrete after \\ being subjected to temperature $T$ \\ $\bar{f}_{\mathrm{c} T} \quad$ mean value of residual compressive strength of the \\ concrete after being subjected to temperature $T$ \\ $f_{\mathrm{dt}} \quad$ direct tensile strength of the concrete at ambient \\ temperature \\ $\bar{f}_{\mathrm{dt}} \quad$ mean value of direct tensile strength of the concrete at \\ ambient temperature \\ $f_{\mathrm{dt} T} \quad$ residual direct tensile strength of the concrete after \\ being subjected to temperature $T$ \\ $\bar{f}_{\text {dt } T} \quad$ mean value of residual direct tensile strength of the \\ concrete after being subjected to temperature $T$ \\ $f_{\mathrm{f}} \quad$ flexural strength of the concrete at ambient temperature \\ $\bar{f}_{\mathrm{f}} \quad$ mean value of flexural strength of the concrete at \\ ambient temperature
}

$f_{\mathrm{f} T} \quad$ residual flexural strength of the concrete after being subjected to temperature $T$

$\bar{f}_{\mathrm{f} T} \quad$ mean value of residual flexural strength of the concrete after being subjected to temperature $T$

$f_{\text {st }} \quad$ splitting tensile strength of the concrete at ambient temperature

$\bar{f}_{\text {st }} \quad$ mean value of splitting tensile strength of the concrete at ambient temperature

$f_{\text {st } T} \quad$ residual splitting tensile strength of the concrete after being subjected to temperature $T$

$\bar{f}_{\text {st } T} \quad$ mean value of residual splitting tensile strength of the concrete after being subjected to temperature $T$

$h$ height

$\sigma \quad$ standard deviation

\section{Introduction}

Reinforced concrete structures are known to have enhanced fire resistance due to their low thermal conductivity and high heat capacity. However, according to Abrams (1983) and Schneider (1988), such structures can be affected to a greater or lesser degree depending on the fire severity. An increase in temperature causes a reduction in the load-bearing capacity of the elements due to degradation of the mechanical properties of the concrete and steel. This degradation in mechanical properties is not uniform in a reinforced concrete element due to the large thermal gradient through its cross-section. On the other hand, internal thermal stresses develop in a concrete matrix, resulting in cracking and/or 


\section{Offprint provided courtesy of www.icevirtuallibrary.com Author copy for personal use, not for distribution}

spalling that can also reduce the load-bearing capacity of an element after fire (Harmathy, 1995; Hertz, 2003; Poon et al., 2001; Santos et al., 2009).

When subjected to high temperature, the mechanical and thermal properties of concrete change according to the ambient conditions and the concrete composition. Among the ambient conditions, the two main factors that influence concrete properties are the heating rate and the maximum temperature attained. These factors lead to changes in the chemical composition and physical structure of the concrete, resulting in the appearance of microcracks, typically at temperatures greater than $300^{\circ} \mathrm{C}$ (Hertz, 2005).

Khoury (1992) and Noumowé (1995) showed that higher heating rates are responsible for greater reductions in the residual compressive strength of concrete. Higher heating rates lead to higher water vapour and pore pressure inside the concrete matrix, resulting in higher values of fracture energy and increasing the risk of spalling. On the other hand, high temperatures result in important physical and chemical changes in the cement paste and aggregates and thermal incompatibility between them, leading to microcracking and concrete degradation (Aitcin, 2003; Bazant and Kaplan, 1996; Castellote et al., 2004; Chan et al., 1999; Georgali and Tsakiridis, 2005; Janotka and Nurnbergerova, 2005; Sakr and El-Hakim, 2005; Schneider, 1992; Ye et al., 2007). The mechanical and thermal properties of concrete at high temperatures are well documented (Hager, 2004; Harmathy, 1970; Husem, 2006), but the same cannot be said about the residual properties after fire exposure.

Several authors have investigated the influence of loading on the residual compressive strength of concrete after being subjected to high temperatures. The results indicate that the loading level, when not high, had a positive effect on the residual compressive strength since specimens subjected to a certain loading showed a lower reduction in this mechanical property than unloaded specimens. This may be due to densification of the concrete cementitious matrix with a limitation on cracking (Hager, 2004; Kodur and Harmathy, 2002).

Abrams (1971) studied the influence of loading level (25-55\% of the compressive strength at ambient temperature) on the compressive strength of ordinary concretes (siliceous, carbonate and sand lightweight aggregate concretes) at high temperatures and the residual strength after heating and cooling. Abrams observed that loading had a positive effect during the heating/cooling process, with loaded specimens presenting a higher compressive strength than unloaded specimens. It was also observed that the residual compressive strength was smaller than the strength at high temperatures. The carbonate and sand lightweight aggregate concretes showed similar behaviour at high temperatures, both with higher strengths than the siliceous aggregate concretes. Khoury (1992) also reported that the application of pre-loading reduced the loss of concrete strength at high temperatures due to compression of the concrete and restrained crack development.
Diederichs et al. (1995), Kodur and Sultan (1998) and Phan and Carino (1998) found that high-strength concretes began to suffer a loss in compressive strength at temperatures lower than for ordinary concretes. Up to $300^{\circ} \mathrm{C}$, high-strength concrete was reported to lose nearly $30 \%$ of its original value, while ordinary concrete retained its original strength or even presented a slight strength increase. In the temperature range $400-800^{\circ} \mathrm{C}$, both concrete types lost most of their initial strength, especially for temperatures higher than $600^{\circ} \mathrm{C}$. At $800^{\circ} \mathrm{C}$, the compressive strength was almost zero for both concretes.

The type of aggregates used and the mix proportions of the concrete constituents may affect its residual compressive strength after fire. Abrams (1983) showed that siliceous aggregate concretes presented a greater decrease in residual compressive strength than calcareous aggregate concretes, although this difference vanished for temperatures above $400^{\circ} \mathrm{C}$.

Schneider and Nãgele (1989) found that the fire extinguishing process is also an important factor in the residual compressive strength of concrete after fire exposure. They reported that concrete cooled with water suffered a greater loss in residual compressive strength than concrete cooled in air.

The residual tensile strength of concrete has been studied by Thelandersson (1971), Noumowé (1995) and Pimienta (1998). The results of tests carried out in these studies showed that there is a relation between the degradation of residual compressive and tensile strengths of concrete after a heating and cooling process. For temperatures above $300^{\circ} \mathrm{C}$, it was verified that concretes of higher compressive strength presented a higher degradation of residual tensile strength. Schneider (1988) showed that the residual tensile strength of concrete after fire is influenced by the type of aggregates used and the concrete composition. It was found that, at a temperature of $500^{\circ} \mathrm{C}$, concretes made with calcareous aggregates had lower residual tensile strength than those made with granite aggregates.

Several studies have indicated that the residual modulus of elasticity of concrete decreases with temperature (Hager, 2004; Noumowé, 1995; Pimienta, 1999; Xiao and Konig, 2003). Schneider and Nãgele (1989) found that quartzite aggregate concretes presented a decrease in residual modulus of elasticity of about $40 \%$ and $85 \%$ after being exposed to temperatures of $300^{\circ} \mathrm{C}$ and $600^{\circ} \mathrm{C}$ respectively.

The mechanical properties of concrete at high temperatures are thus already well known, but knowledge of the residual mechanical properties of concrete after fire is not well consolidated and the results of experimental tests carried out by different researchers present some inconsistencies. Research on this theme was therefore conducted at the University of Coimbra with the aim of assessing the residual mechanical properties of calcareous aggregate concrete (CC) and granite aggregate concrete (GC), with and without fibres, after fire. 


\section{Offprint provided courtesy of www.icevirtuallibrary.com Author copy for personal use, not for distribution}

\section{Materials and methods}

The influence of temperature, loading level and cooling process on the residual mechanical properties of $\mathrm{GC}$ and $\mathrm{CC}$ after fire was investigated. The properties assessed were residual compressive, tensile and flexural strengths and modulus of elasticity.

After being subjected to different temperatures (300, 500 and $700^{\circ} \mathrm{C}$ ) the concrete specimens were cooled to ambient temperature and tested for the different mechanical properties. Tests were also carried out at ambient temperature (around $20^{\circ} \mathrm{C}$ ) to obtain reference values of the mechanical properties of the concretes. The cooling processes tested were cooling in air, to simulate a fire that died naturally, and cooling with water jets to simulate a fire extinguished by firefighters.

In the compressive strength tests, during the heating and cooling processes, the concrete was subjected to compressive loading that attempted to simulate the loading conditions of concrete in real structures. The loading levels used were a percentage of the design value of the compressive strength of the concrete at ambient temperature (i.e. $0 \cdot 3 f_{\mathrm{cd}}$ and $0 \cdot 7 f_{\mathrm{cd}}$ ). The specimens used for assessing other mechanical properties were heated and cooled without loading before being mechanically tested.

\section{Concrete compositions}

Two concrete compositions were tested, one with calcareous aggregates (CC) and one with granite aggregates (GC). The mixes comprised Portland cement type II/AL $42 \cdot 5 \mathrm{R}$ (with sulfur trioxide $\leqslant 4 \%$ and chlorine $\leqslant 0 \cdot 10 \%$; compressive strength $20 \mathrm{MPa}(2 \mathrm{~d})$ and $42.5 \mathrm{MPa}(28 \mathrm{~d})$ ), superplasticiser (SP) SIKA (Sikament 195R) and four types of aggregate - fine sand (A1), coarse sand (A2) and crushed stone $(12.7 \mathrm{~mm}$ (B1) and $19.1 \mathrm{~mm}$ (B2)). The mix compositions are shown in Table 1.

\section{Specimens}

The specimens prepared for residual compressive and direct tensile strength tests were cylinders of diameter $d=75 \mathrm{~mm}$ and height $h=225 \mathrm{~mm}(d / h=1: 3)$. These dimensions were determined taking into account the dimensions of the electric tube oven available for the tests and $d / h$ ratio according to the recommendations of RILEM TC 200-HTC (2005). The temperature of the specimens was recorded at five locations using type $\mathrm{K}$ thermocouples. The position of the thermocouples was also defined following RILEM TC 200-HTC (2005): three points on the surface and two points along the central axis of the specimen as shown in Figure 1(a).
The specimens used for residual splitting tensile strength and modulus of elasticity tests were cylinders of $150 \mathrm{~mm}$ diameter and $300 \mathrm{~mm}$ height (Figure 1(b)) (CEN, 2003; RILEM TC 129MHT, 2004). For the modulus of elasticity tests, strain gauges (TMLs PFL-30-11) set at angles of $120^{\circ}$ to each other were used to measure strains. The specimens for the residual flexural strength tests were prisms of $150 \mathrm{~mm} \times 150 \mathrm{~mm} \times 600 \mathrm{~mm}$ (Figure 1(c)) (CEN, 2009).

The positions of the thermocouples in the specimens used to test residual splitting tensile strength, modulus of elasticity and flexural strength followed the same philosophy as the residual compressive strength tests (i.e. RILEM TC 200-HTC (2005) recommendations) (Figure 1(b) and 1(c)). They were also type $\mathrm{K}$ thermocouples.

\section{Test plan}

The prepared specimens were cured in a vapour-saturated chamber (relative humidity $\mathrm{RH}>98 \%$, temperature $20^{\circ} \mathrm{C}$ ) for $28 \mathrm{~d}$. They were then removed and left in the laboratory at an ambient temperature of $18-20^{\circ} \mathrm{C}$ and $\mathrm{RH}=40-50 \%$. The specimens were tested at a minimum age of 3 months.

The test plan shown in Table 2 shows the characteristics of the specimens, the loading level and the maximum temperatures to which the specimens were subjected. For each combination of parameters, at least three tests were carried out.

\section{Residual compressive strength tests}

The experimental setup for the residual compressive strength tests comprised a universal tensile/compression machine of $600 \mathrm{kN}$ capacity and an attached electric tube oven to heat the specimens (Figure 2(a)). The oven had internal dimensions of $d=125 \mathrm{~mm}$ and $h=300 \mathrm{~mm}$ and a maximum working temperature of $1200^{\circ} \mathrm{C}$. The two cooling processes adopted in the tests were realised either by opening the oven and leaving the specimen inside to cool slowly in air (Figure 2(b)) or by spraying with water after opening the oven and pushing it to the rear (Figure $2(\mathrm{c})$ ). In the water cooling process, the flow was around $3.9 \times 10^{-4} \mathrm{~m}^{3} / \mathrm{s}$ and pressure was $3.5 \times 10^{5} \mathrm{~Pa}$.

The heating process followed RILEM TC 200-HTC (2005) recommendations. The specimen was first loaded to the required level $\left(0 \cdot 3 f_{\text {cd }}\right.$ or $\left.0 \cdot 7 f_{\text {cd }}\right)$ and then the temperature was increased at a rate of $3^{\circ} \mathrm{C} / \mathrm{min}$ until the desired temperature $(300,500$ or $700^{\circ} \mathrm{C}$ ) was reached. In some cases, specimens ruptured during

\begin{tabular}{ccccccccc}
\hline & Cement: $\mathrm{kg} / \mathrm{m}^{3}$ & Water: $\mathrm{dm}^{3} / \mathrm{m}^{3}$ & $\mathrm{SP}: \mathrm{dm}^{3} / \mathrm{m}^{3}$ & $\mathrm{~A} 1: \mathrm{kg} / \mathrm{m}^{3}$ & $\mathrm{~A} 2: \mathrm{kg} / \mathrm{m}^{3}$ & B1: $\mathrm{kg} / \mathrm{m}^{3}$ & B2: $\mathrm{kg} / \mathrm{m}^{3}$ & w/c ratio \\
\hline CC & 300 & 166 & $3 \cdot 30$ & 364 & 495 & 505 & 377 & $0 \cdot 56$ \\
GC & 320 & 165 & $3 \cdot 20$ & 310 & 511 & 617 & 459 & $0 \cdot 52$
\end{tabular}

Table 1. Compositions of calcareous aggregate concrete (CC)

and granite aggregate concrete (GC) 


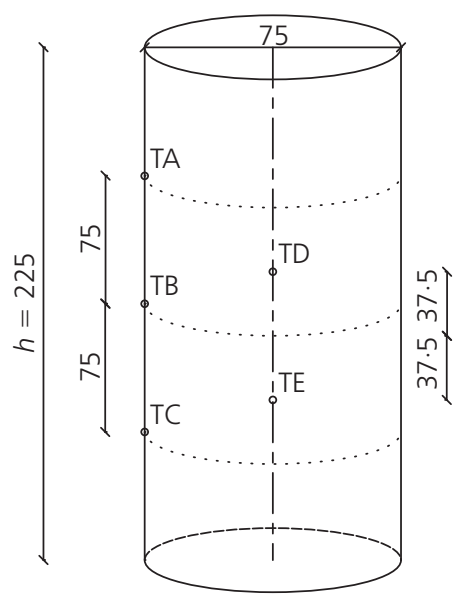

(a)

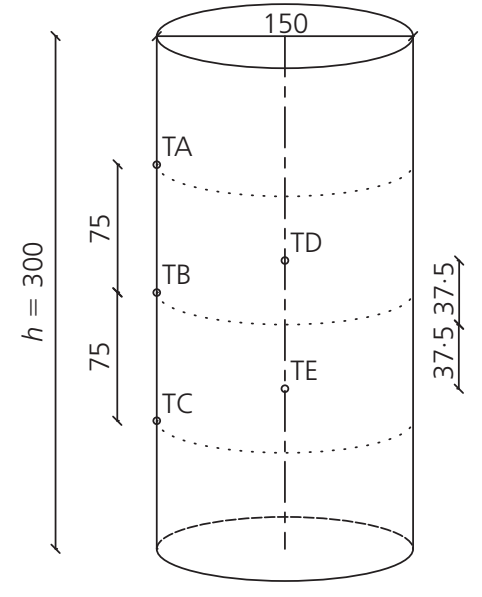

(b)

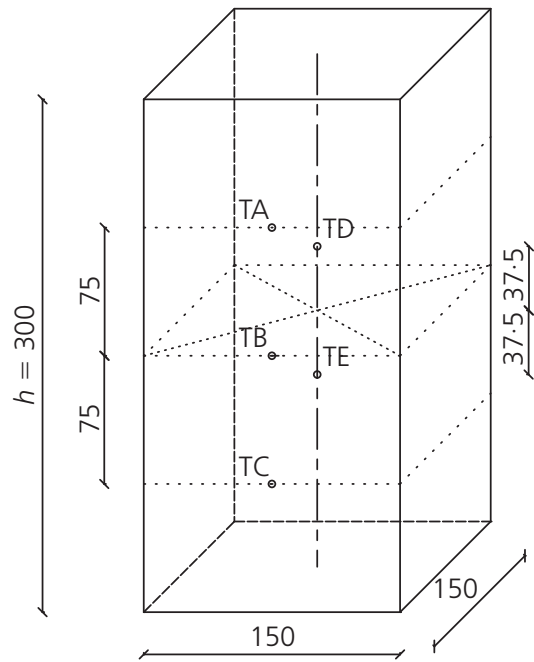

(c)

Figure 1. Specimens and location of thermocouples;

(a) compressive and direct tensile strength tests; (b) splitting tensile strength and modulus of elasticity tests; (c) flexural strength tests; dimensions in $\mathrm{mm}$

\begin{tabular}{|c|c|c|c|c|c|}
\hline \multirow[t]{2}{*}{ Test } & \multirow[t]{2}{*}{ Specimen } & \multirow[t]{2}{*}{ Dimensions: mm } & \multicolumn{2}{|c|}{ Load level: kN } & \multirow[t]{2}{*}{ Temperature: ${ }^{\circ} \mathrm{C}$} \\
\hline & & & $\mathrm{CC}$ & $\mathrm{GC}$ & \\
\hline \multirow[t]{2}{*}{ Compressive strength } & Cylinder & $d=75, h=200$ & $30 \cdot 8$ & $28 \cdot 0$ & $20,300,500,700$ \\
\hline & Cylinder & $d=75, h=200$ & $71 \cdot 8$ & $65 \cdot 3$ & \\
\hline Direct tensile strength & Cylinder & $d=75, h=200$ & - & - & $20,300,500,700$ \\
\hline Splitting strength & Cylinder & $d=150, h=300$ & - & - & $20,300,500,700$ \\
\hline Flexural strength & Prism & $b=150, h=600$ & - & - & $20,300,500,700$ \\
\hline Modulus of elasticity & Cylinder & $d=150, h=300$ & - & - & $20,300,500,700$ \\
\hline
\end{tabular}

Table 2. Test plan

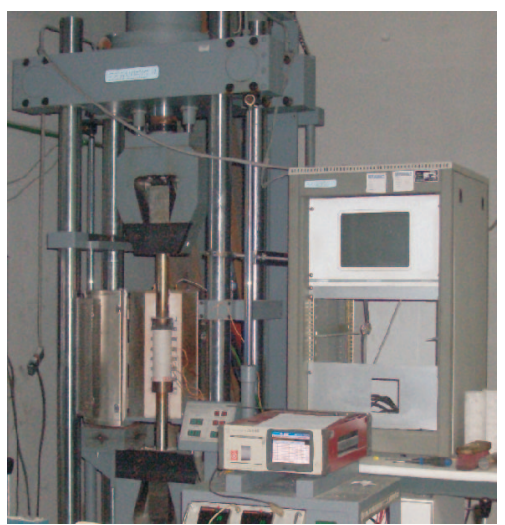

(a)

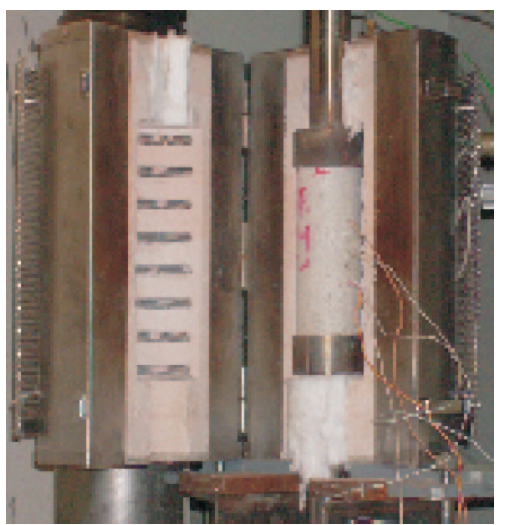

(b)

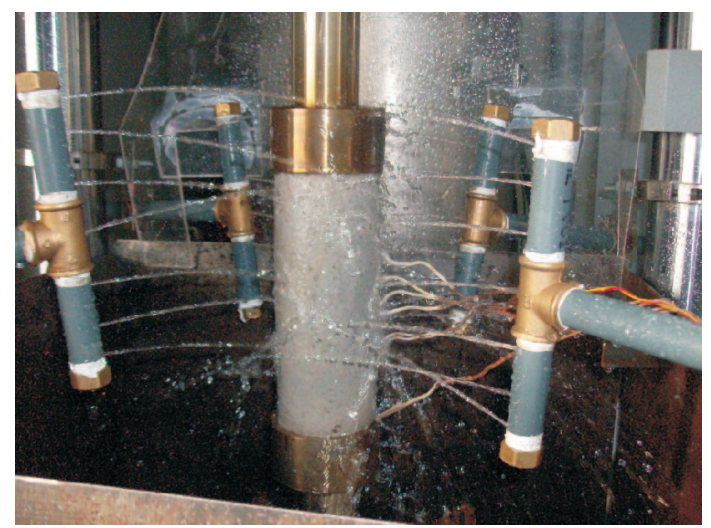

(c)

Figure 2. Residual compressive strength testing: (a) test setup;

(b) cooling in air; (c) cooling with water jets 
heating before reaching the desired temperature. In this scenario, subsequent specimens in the series were heated to an intermediate temperature (for example, tests were carried out at $600^{\circ} \mathrm{C}$ when specimens in a series had collapsed before reaching $700^{\circ} \mathrm{C}$ ). On the other hand, for specimens withstanding the $700^{\circ} \mathrm{C}$ test series without problem, tests were also carried out at $900^{\circ} \mathrm{C}$. The initial applied load was kept constant during the entire heating/cooling process.

The target specimen temperature was considered to have been achieved when the average temperature recorded by the three superficial thermocouples on the specimen matched the oven temperature. The maximum axial temperature differences between the superficial temperature readings could not exceed $1{ }^{\circ} \mathrm{C}$ at $20^{\circ} \mathrm{C}, 5^{\circ} \mathrm{C}$ at $100^{\circ} \mathrm{C}$ and $20^{\circ} \mathrm{C}$ at $700^{\circ} \mathrm{C}$. The specimen was then kept at that temperature for 1 hour to stabilise, according to RILEM TC 200-HTC (2005). The specimen was then cooled (in air or with water jets) to ambient temperature and when the temperature reached $\approx 20^{\circ} \mathrm{C}$ the compressive strength test was carried out soon after. The load was increased at a rate of $0.25 \mathrm{kN} / \mathrm{s}$ up to rupture of the specimen.

\section{Residual tensile strength tests}

Residual tensile strength was determined through direct tensile and tensile splitting tests (Figure 3). The heating and cooling processes were similar to those used for residual compressive strength tests, but the specimens were not subjected to loading during heating/cooling. The oven used to heat the specimens in

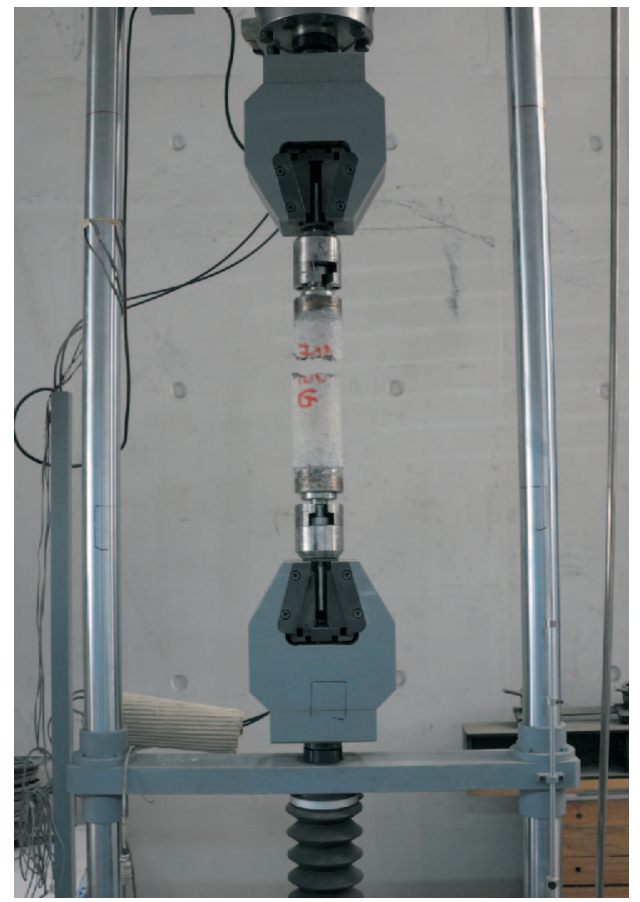

(a) the direct tensile tests was the same as that used for compressive strength tests. For the splitting tensile tests, an oven with a prismatic chamber of internal dimensions $135 \times 140 \times 250 \mathrm{~mm}$ and a maximum working temperature of $1200^{\circ} \mathrm{C}$ was used. As in the compressive strength tests, some specimens were cooled in air and others by water jets. The specimens were tested soon after heating and cooling. The time taken between the first and the last test of each series was nearly 1 week and, during this time, the specimens waiting for testing were left in the ambient temperature and humidity conditions of the laboratory.

For the direct tensile strength tests, the specimens were tested under direct tensile load in a universal tensile/compression machine with a maximum load capacity of $200 \mathrm{kN}$. The load was increased at a rate of $0.25 \mathrm{kN} / \mathrm{s}$ until rupture of the specimen. A special set of steel pull-rods that allowed free rotation of the specimen at its ends was built for these tests (Figure 3(a)).

For the splitting tensile strength tests, testing was carried out according to EN 12390-6 (CEN, 2003) (the Brazilian test or indirect tensile test). The test setup was built and mounted according to this standard in a tensile/compression machine of $600 \mathrm{kN}$ capacity (Figure 3(b)).

\section{Residual flexural strength tests}

The heating/cooling process and conditioning of the specimens were similar to those used in the residual splitting tensile tests. The specimens were then subjected to flexural testing, in the

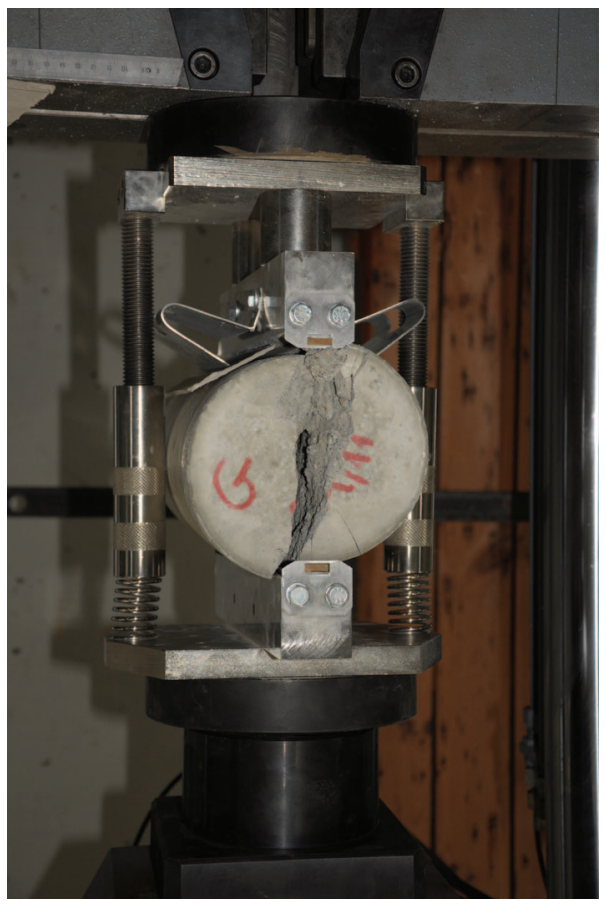

(b)

Figure 3. Residual tensile strength tests: (a) direct tensile test; (b) tensile splitting test 
$600 \mathrm{kN}$ tensile/compression machine, using a special device for this type of test. The load was increased at a rate of $0.05 \mathrm{MPa} / \mathrm{s}$ until rupture of the specimen. The procedure used corresponded to EN 12390-5 (CEN, 2009) (Figure 4).

\section{Residual modulus of elasticity}

The heating/cooling process and conditioning of the specimens again followed the procedures for the prior tests. The residual modulus of elasticity tests were carried out according to RILEM TC 129-MHT (2004). The specimens were subjected to cyclic loading in the $600 \mathrm{kN}$ tensile/compression machine. The loading cycles were between $0 \cdot 5 \mathrm{MPa}$ and $f_{\mathrm{c}} / 3$. A special set of rings for determining the modulus of elasticity was used. Strain gauges bonded onto the surface of the specimen allowed measurement of the strains for indirect determination of the modulus of elasticity (Figure 5).

\section{Results}

Residual compressive strength

To allow a more comprehensive analysis of the results of the compressive strength tests, Tables 3 and 4 summarise the values registered and statistical analysis for $\mathrm{CC}$ and $\mathrm{GC}$ respectively.

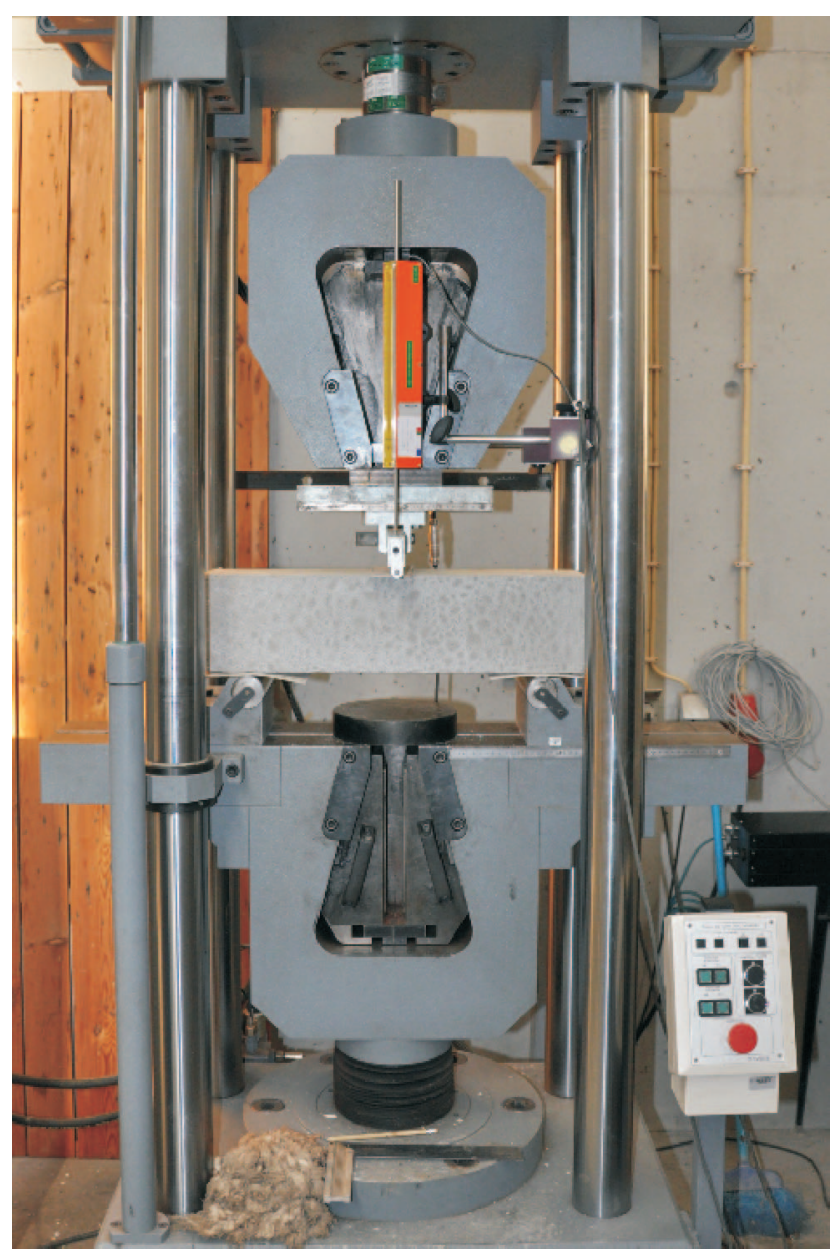

Figure 4. Test setup for residual flexural strength tests

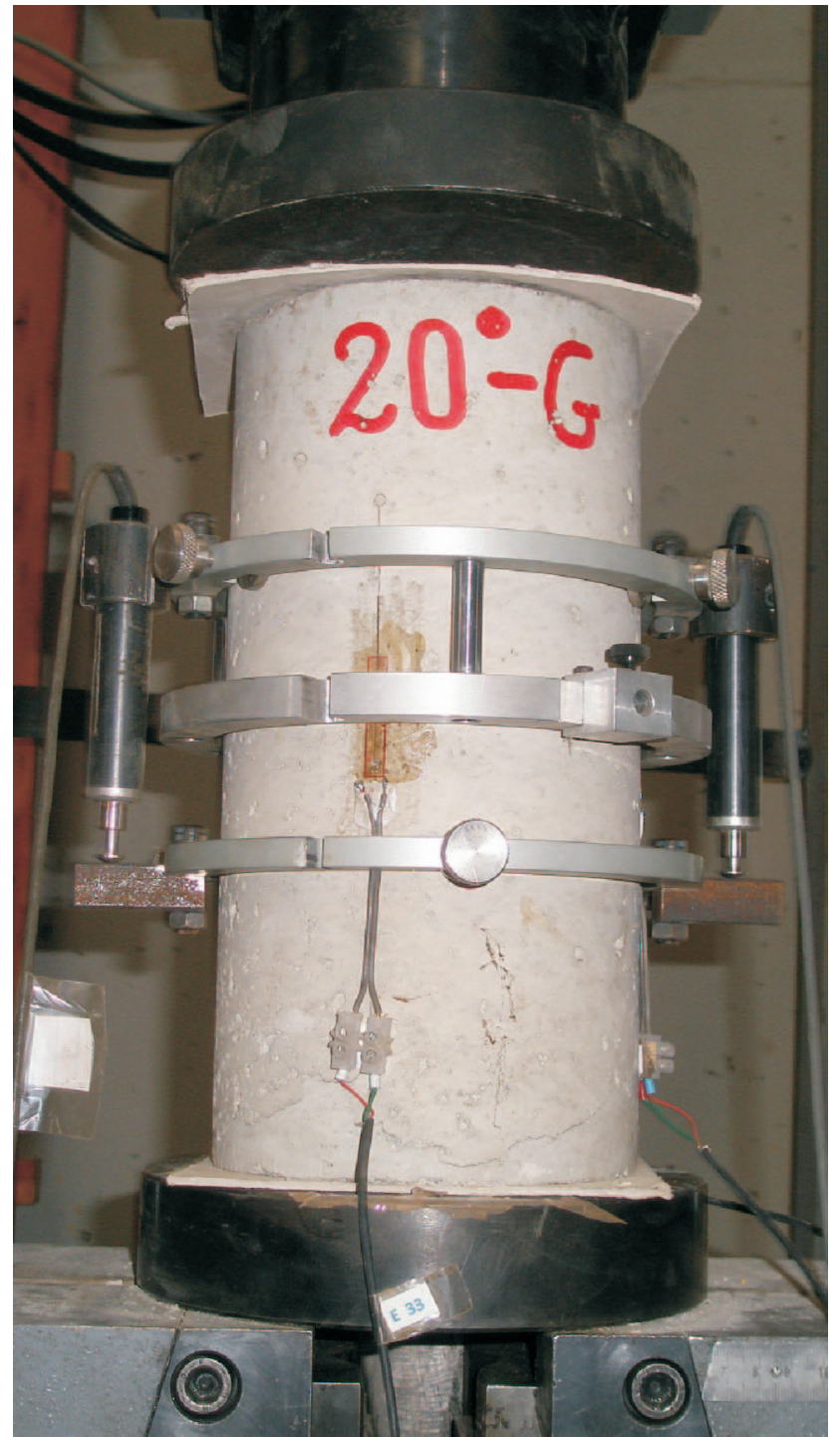

Figure 5. Test setup for residual modulus of elasticity tests

Figure 6(a) shows, for a loading level of $0 \cdot 3 f_{\text {cd }}$ and the two cooling processes, the variation of residual compressive strength of $\mathrm{CC}$ and $\mathrm{GC}$ in relation to the values at ambient temperature as a function of the maximum temperature to which the concretes were subjected. The figure shows that both $\mathrm{CC}$ and $\mathrm{GC}$ experienced a reduction in residual compressive strength with an increase in temperature. Furthermore, for both types of cooling, the reduction in residual compressive strength was greater for CC than for GC. Cooling with water jets led to higher strength reductions in the temperature range $20-800^{\circ} \mathrm{C}$. The values of residual compressive strength of the water-cooled $\mathrm{GC}$ tended to those of the air-cooled samples and both were zero for temperatures of nearly $800^{\circ} \mathrm{C}$.

The residual compressive strengths of $\mathrm{CC}$ and $\mathrm{GC}$ for a loading level of $0 \cdot 7 f_{\mathrm{cd}}$ and both cooling processes are shown in Figure 


\begin{tabular}{|c|c|c|c|c|c|}
\hline Cooling/load level & $\begin{array}{l}\text { Temperature: } \\
{ }^{\circ} \mathrm{C}\end{array}$ & $\begin{array}{c}f_{\mathrm{c}} \text { or } f_{\mathrm{cT}}: \\
\mathrm{MPa}\end{array}$ & $\begin{array}{c}\bar{f}_{\mathrm{c}} \text { or } \bar{f}_{\mathrm{cT}}: \\
\mathrm{MPa}\end{array}$ & $\sigma$ & $\bar{f}_{\mathrm{cT}} / \bar{f}_{\mathrm{c}}$ \\
\hline & 20 & $\begin{array}{l}36.67 \\
38.86 \\
37.71\end{array}$ & $37 \cdot 75$ & $1 \cdot 10$ & 1.00 \\
\hline \multicolumn{6}{|l|}{ Air cooling } \\
\hline \multirow[t]{3}{*}{$0 \cdot 3 f_{c d}$} & 300 & $\begin{array}{l}33 \cdot 88 \\
32.93 \\
29 \cdot 33\end{array}$ & 32.05 & $2 \cdot 40$ & 0.85 \\
\hline & 500 & $\begin{array}{l}20 \cdot 16 \\
21 \cdot 34 \\
21 \cdot 30\end{array}$ & $20 \cdot 93$ & 0.67 & 0.55 \\
\hline & 700 & - & TS & - & 0.00 \\
\hline \multirow[t]{3}{*}{$0.7 f_{\mathrm{cd}}$} & 300 & $\begin{array}{l}32 \cdot 14 \\
31 \cdot 65 \\
32.94\end{array}$ & $32 \cdot 25$ & 0.65 & 0.85 \\
\hline & 500 & $\begin{array}{c}27 \cdot 55 \\
\text { STS } \\
\text { STS }\end{array}$ & $27 \cdot 55$ & - & 0.73 \\
\hline & \multicolumn{4}{|c|}{ Water jet cooling } & 0.00 \\
\hline \multirow[t]{3}{*}{$0.3 f_{\mathrm{cd}}$} & 300 & $\begin{array}{c}19 \cdot 30 \\
23 \cdot 60 \\
\text { STS }\end{array}$ & $21 \cdot 45$ & 3.04 & 0.57 \\
\hline & 500 & $\begin{array}{c}11 \cdot 25 \\
11 \cdot 32 \\
\text { STS }\end{array}$ & $11 \cdot 28$ & 0.05 & 0.30 \\
\hline & 700 & - & C & - & 0.00 \\
\hline $0.7 f_{\mathrm{cd}}$ & 300 & - & C & - & 0.00 \\
\hline
\end{tabular}

Table 3. Residual compressive strength of CC: TS, specimen rupture during temperature stabilisation; STS, specimen rupture at start of temperature stabilisation; $\mathrm{H}$, specimen rupture during heating phase; $\mathrm{C}$, specimen rupture during cooling phase

6(b). In the case of cooling in air, for temperatures up to $300^{\circ} \mathrm{C}$, GC showed higher values of residual compressive strength than CC. However, for higher temperatures, the opposite trend was found: GC showed a sharp decrease in residual compressive strength to zero at around $400^{\circ} \mathrm{C}$ while at the same temperature CC still showed nearly $80 \%$ of the compressive strength value at ambient temperature.

Comparison of Figures 6(a) and 6(b) indicates that the loading level seems to affect GC more than CC. The improved performance of GC in relation to CC disappears at the higher loading level. For air-cooled $\mathrm{GC}$ for a loading level of $0.3 f_{\mathrm{cd}}$, the compressive strength at $400^{\circ} \mathrm{C}$ was still about $95 \%$ of the value at ambient temperature, but the strength was zero at this temperature for a load of $0 \cdot 7 f_{\text {cd }}$. The same is not true for CC: for a temperature of $400^{\circ} \mathrm{C}$ and cooling in air, the compressive strength of CC was about $70 \%$ and $80 \%$ of its value at ambient temperature for loading levels of $0 \cdot 3 f_{\text {cd }}$ and $0.7 f_{\text {cd }}$ respectively. The CC presented zero residual strength only for temperatures of $700^{\circ} \mathrm{C}$ and $650^{\circ} \mathrm{C}$ for $0 \cdot 3 f_{\text {cd }}$ and $0 \cdot 7 f_{\text {cd }}$ respectively. A similar behaviour was observed in the case of cooling by water jets.

The cooling process, especially cooling by water jets, for a load of $0.7 f_{\text {cd }}$ seems to have a significant influence on the residual compressive strength of the concrete.

\section{Residual tensile strength}

\section{Direct tensile strength}

Tables 5 and 6 show the residual direct tensile strengths of CC and GC respectively, along with statistical analysis. The results are also plotted as a function of the maximum temperature to which the concrete was subjected in Figure 7.

Figure 7 shows that GC in general showed better performance than $\mathrm{CC}$ for both cooling processes, presenting smaller reductions in residual direct tensile strength as a function of temperature. Considering the two processes used, it seems that, regardless of aggregate type, the concretes were less affected by air cooling 


\begin{tabular}{|c|c|c|c|c|c|}
\hline Cooling/load level & $\begin{array}{l}\text { Temperature: } \\
{ }^{\circ} \mathrm{C}\end{array}$ & $\begin{array}{c}f_{\mathrm{c}} \text { or } f_{\mathrm{cT}}: \\
\mathrm{MPa}\end{array}$ & $\begin{array}{c}\bar{f}_{\mathrm{c}} \text { or } \bar{f}_{\mathrm{CT}}: \\
\mathrm{MPa}\end{array}$ & $\sigma$ & $\bar{f}_{C T} / \bar{f}_{c}$ \\
\hline & 20 & $\begin{array}{l}21.96 \\
23 \cdot 65 \\
25 \cdot 59\end{array}$ & $23 \cdot 73$ & $1 \cdot 81$ & 1.00 \\
\hline \multicolumn{6}{|l|}{ Air cooling } \\
\hline $0.3 f_{c d}$ & 300 & $\begin{array}{l}26 \cdot 07 \\
20 \cdot 64 \\
27 \cdot 13\end{array}$ & $24 \cdot 61$ & $3 \cdot 48$ & 1.04 \\
\hline & 500 & $\begin{array}{l}20 \cdot 50 \\
19 \cdot 99 \\
20 \cdot 35\end{array}$ & $20 \cdot 28$ & 0.27 & 0.85 \\
\hline & 700 & $\begin{array}{r}8.97 \\
9.21 \\
10.67\end{array}$ & $9 \cdot 62$ & 0.92 & 0.41 \\
\hline & 900 & - & H & - & 0.00 \\
\hline $0.7 f_{c d}$ & 300 & $\begin{array}{l}24 \cdot 32 \\
25 \cdot 59 \\
\text { TS }\end{array}$ & 24.95 & 0.90 & 1.05 \\
\hline & 500 & - & $\mathrm{H}$ & - & 0.00 \\
\hline $\begin{array}{l}\text { Water jet cooling } \\
0.3 f_{\text {cd }}\end{array}$ & 300 & $\begin{array}{l}17.02 \\
12.84 \\
15.98\end{array}$ & $15 \cdot 28$ & $2 \cdot 17$ & 0.64 \\
\hline & 500 & $\begin{array}{r}9.90 \\
10.93 \\
12.09\end{array}$ & $10 \cdot 97$ & $1 \cdot 10$ & 0.46 \\
\hline & 700 & $\begin{array}{l}6.80 \\
6.98 \\
7.18\end{array}$ & $6 \cdot 98$ & $1 \cdot 10$ & 0.29 \\
\hline $0.7 f_{c d}$ & 900 & - & $\mathrm{H}$ & - & 0.00 \\
\hline
\end{tabular}

Table 4. Residual compressive strength of GC: $\mathrm{H}$, specimen rupture during heating phase; TS, specimen rupture during temperature stabilisation

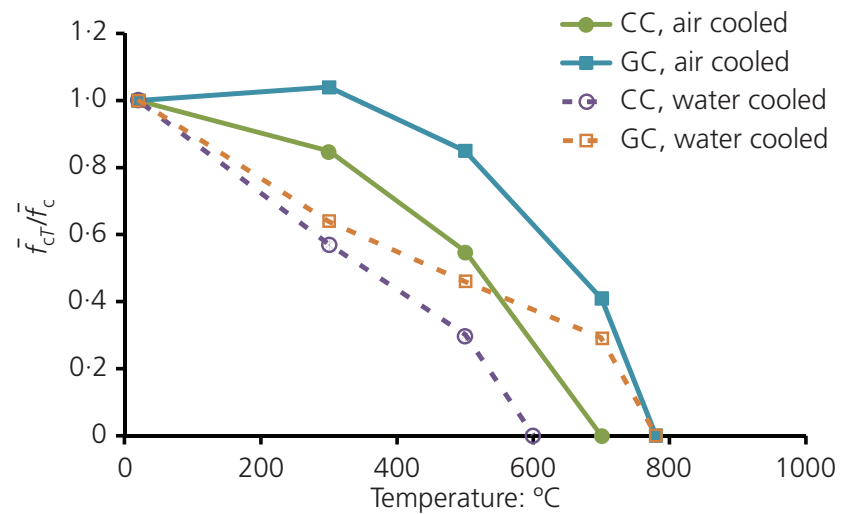

(a)

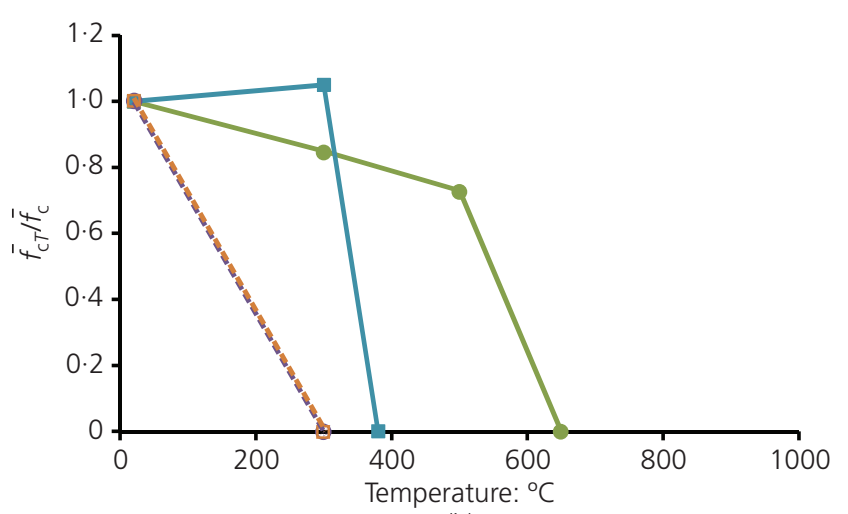

(b)

Figure 6. Residual compressive strength of CC and GC for loading levels of (a) $0 \cdot 3 f_{\mathrm{cd}}$ and (b) $0 \cdot 7 f_{\mathrm{cd}}$ 


\begin{tabular}{lcccc}
\hline $\begin{array}{l}\text { Temperature: } \\
{ }^{\circ} \mathrm{C}\end{array}$ & $\begin{array}{c}f_{\mathrm{dt}} \text { or } f_{\mathrm{dtt} T}: \\
\mathrm{MPa}\end{array}$ & $\begin{array}{c}\bar{f}_{\mathrm{dt}} \text { or } \bar{f}_{\mathrm{dt} T}: \\
\mathrm{MPa}\end{array}$ & $\sigma$ & $\bar{f}_{\mathrm{dtt} T} / \bar{f}_{\mathrm{dt}}$ \\
\hline 20 & 2.29 & 2.28 & 0.36 & 1.00 \\
& 1.91 & & & \\
& 2.64 & & & \\
& & &
\end{tabular}

\begin{tabular}{|c|c|c|c|c|}
\hline $\begin{array}{l}\text { Temperature: } \\
{ }^{\circ} \mathrm{C}\end{array}$ & $\begin{array}{c}f_{\mathrm{dt}} \text { or } f_{\mathrm{dtt}}: \\
\mathrm{MPa}\end{array}$ & $\begin{array}{c}\bar{f}_{\mathrm{dt}} \text { or } \bar{f}_{\mathrm{dtt}}: \\
\mathrm{MPa}\end{array}$ & $\sigma$ & $\bar{f}_{\mathrm{dt} T} / \bar{f}_{\mathrm{dt}}$ \\
\hline 20 & $\begin{array}{l}1.95 \\
1.39 \\
2.48\end{array}$ & 1.94 & 0.54 & 1.00 \\
\hline Air cooling & & & & \\
\hline 300 & $\begin{array}{l}0.91 \\
1.32 \\
1.54\end{array}$ & $1 \cdot 26$ & 0.32 & 0.65 \\
\hline 500 & $\begin{array}{l}0.46 \\
0.52 \\
0.40\end{array}$ & 0.46 & 0.06 & 0.24 \\
\hline 700 & $\begin{array}{l}0.19 \\
0.15 \\
0.14\end{array}$ & $0 \cdot 16$ & 0.02 & 0.08 \\
\hline Water jet cool & & & & \\
\hline 300 & $\begin{array}{l}1.28 \\
1.03 \\
0.80\end{array}$ & 1.04 & 0.24 & 0.53 \\
\hline 500 & $\begin{array}{l}0.72 \\
0.33 \\
0.62\end{array}$ & 0.56 & 0.21 & 0.29 \\
\hline 700 & 0.42 & 0.44 & 0.04 & 0.23 \\
\hline
\end{tabular}

Table 5. Residual direct tensile strength of CC: C, specimen rupture during cooling phase

than water cooling for temperatures up to about $500^{\circ} \mathrm{C}$. The opposite was observed above $500^{\circ} \mathrm{C}$ : cooling in air gave a greater reduction in residual direct tensile strength for both concretes. The reduction in residual tensile strength of the concrete can be explained by dehydration of the clinker in the cement paste, especially calcium hydroxide, and the thermal incompatibility between the cement paste and the aggregates (Thelandersson, 1971).

\section{Tensile splitting strength}

The residual tensile splitting strength results are shown in Tables 7 and 8 and Figure 8. For both types of concrete, the behaviour was similar for the two cooling processes used. There was not a marked difference between air cooling and water cooling, both leading to quite similar reductions in residual tensile splitting strength.

For temperatures up to $300^{\circ} \mathrm{C}$, all the concretes studied presented similar behaviour. Above this temperature, GC showed greater reductions in residual tensile splitting strength than $\mathrm{CC}$. For both cooling processes, the residual tensile splitting strength of GC was zero at $500^{\circ} \mathrm{C}$ while, at the same temperature, $\mathrm{CC}$ strengths were still around $20 \%$ and $30 \%$ of the ambient strength values for water cooling and air cooling respectively. All GC specimens

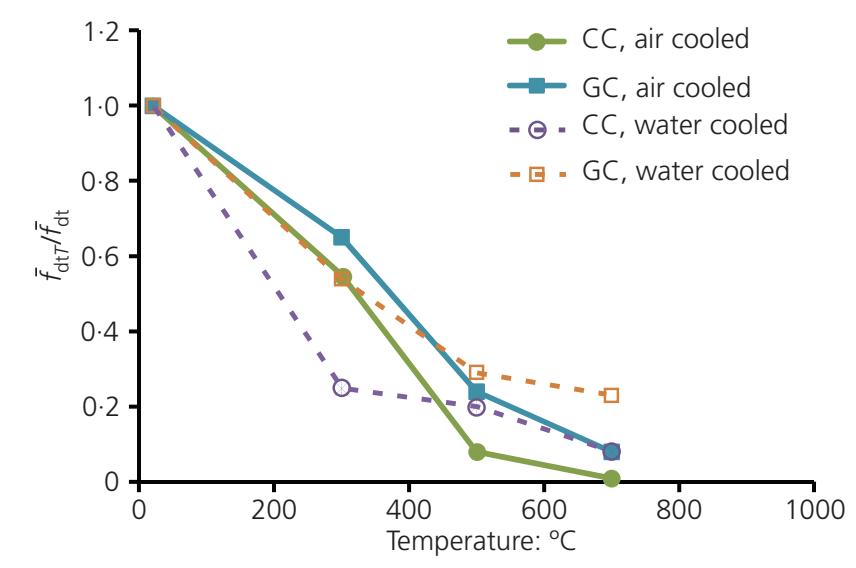

Figure 7. Residual direct tensile strength of CC and GC

submitted to temperatures greater than or equal to $500^{\circ} \mathrm{C}$ collapsed during the heating process (Table 8). This can be explained by the low porosity of GC compared with CC (Sims and Brown, 1998).

The residual direct tensile strength results were, to some extent, different to the residual tensile splitting strength results: the decrease in strength with temperature was greater for the direct tensile strength tests. A conclusion from this is difficult to draw 


\begin{tabular}{|c|c|c|c|c|}
\hline $\begin{array}{l}\text { Temperature: } \\
{ }^{\circ} \mathrm{C}\end{array}$ & $\begin{array}{c}f_{\mathrm{st}} \text { or } f_{\mathrm{st} T}: \\
\mathrm{MPa}\end{array}$ & $\begin{array}{c}\bar{f}_{\mathrm{st}} \text { or } \bar{f}_{\mathrm{st} T} \\
\mathrm{MPa}\end{array}$ & $\sigma$ & $\bar{f}_{\mathrm{st} T} / \bar{f}_{\mathrm{st}}$ \\
\hline 20 & $\begin{array}{l}3 \cdot 015 \\
2 \cdot 664 \\
3 \cdot 330\end{array}$ & 3.003 & 0.333 & $1 \cdot 00$ \\
\hline \multicolumn{5}{|l|}{ Air cooling } \\
\hline 300 & $\begin{array}{l}1.922 \\
1.819 \\
1.967\end{array}$ & 1.902 & 0.076 & 0.63 \\
\hline 500 & $\begin{array}{l}0.807 \\
0.977 \\
0.874\end{array}$ & 0.886 & 0.085 & $0 \cdot 30$ \\
\hline 700 & $\begin{array}{l}0.327 \\
0.280 \\
0.213\end{array}$ & 0.274 & 0.057 & 0.09 \\
\hline \multicolumn{5}{|c|}{ Water jet cooling } \\
\hline 300 & $\begin{array}{l}1.751 \\
1.905 \\
1.830\end{array}$ & $1 \cdot 829$ & 0.077 & 0.61 \\
\hline 500 & $\begin{array}{l}0.949 \\
0.980 \\
0.892\end{array}$ & 0.941 & 0.044 & $0 \cdot 31$ \\
\hline 700 & $\begin{array}{l}0.355 \\
0.415 \\
0.325\end{array}$ & $0 \cdot 365$ & 0.046 & $0 \cdot 12$ \\
\hline
\end{tabular}

Table 7. Residual tensile splitting strength of CC

\begin{tabular}{lcccc}
\hline $\begin{array}{l}\text { Temperature: } \\
{ }^{\circ} \mathrm{C}\end{array}$ & $\begin{array}{c}f_{\text {st }} \text { or } f_{\text {st } T}: \\
\mathrm{MPa}\end{array}$ & $\begin{array}{c}\bar{f}_{\text {st }} \text { or } \bar{f}_{\text {st } T}: \\
\mathrm{MPa}\end{array}$ & $\sigma$ & $\bar{f}_{\text {st } T} / \bar{f}_{\text {st }}$ \\
\hline 20 & 2.922 & 2.922 & 0.12 & 1.00 \\
& 3.039 & & & \\
& 2.805 & & & \\
& & & &
\end{tabular}

Air cooling

$\begin{array}{lllll}300 & 2.606 & 2.295 & 0.27 & 0.79 \\ 2.102 & & & \end{array}$

$\begin{array}{lcccc}500 & - & \mathrm{H} & & 0.00 \\ 700 & - & \mathrm{H} & & - \\ \text { Water jet cooling } & & & & \\ 300 & 1.572 & 1.746 & 0.15 & 0.60 \\ & 1.826 & & & \\ & 1.841 & & & \end{array}$

$\begin{array}{cccc}500 & - & \mathrm{H} & 0.00 \\ 700 & - & \mathrm{H} & -\end{array}$

Table 8. Residual tensile splitting strength of GC: $H$, specimen rupture during heating phase

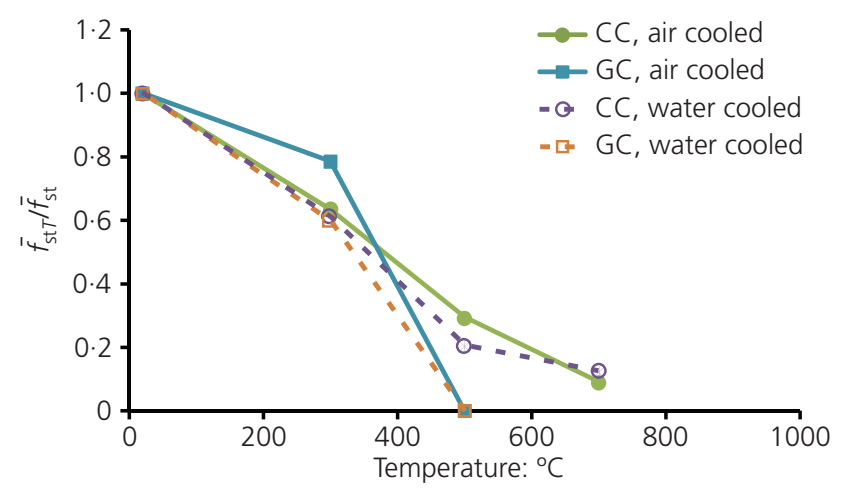

Figure 8. Residual splitting tensile strength of CC and GC

because, apart from the fact that the two types of tests were different, the specimens used for the residual direct tensile strength tests were cylinders of $75 \mathrm{~mm}$ diameter and $225 \mathrm{~mm}$ height while those used for residual splitting tensile tests were cylinders of $150 \mathrm{~mm}$ diameter and $300 \mathrm{~mm}$ height.

\section{Residual flexural strength}

The results of residual flexural strength for $\mathrm{CC}$ and GC are listed in Tables 9 and 10 and presented graphically in Figure 9. The results indicate a decrease in residual flexural strength with

\begin{tabular}{|c|c|c|c|c|}
\hline $\begin{array}{l}\text { Temperature: } \\
{ }^{\circ} \mathrm{C}\end{array}$ & $\begin{array}{c}f_{\mathrm{f}} \text { or } f_{\mathrm{fT}}: \\
\mathrm{MPa}\end{array}$ & $\begin{array}{c}\bar{f}_{\mathrm{f}} \text { or } \bar{f}_{\mathrm{fT}}: \\
\mathrm{MPa}\end{array}$ & $\sigma$ & $\bar{f}_{\mathrm{f} T} / \bar{f}_{\mathrm{f}}$ \\
\hline 20 & $\begin{array}{l}3 \cdot 914 \\
6 \cdot 566 \\
5 \cdot 160\end{array}$ & $5 \cdot 213$ & $1 \cdot 32$ & 1.00 \\
\hline \multicolumn{5}{|l|}{ Air cooling } \\
\hline 300 & $\begin{array}{l}3 \cdot 076 \\
3 \cdot 394 \\
3 \cdot 226\end{array}$ & $3 \cdot 232$ & $0 \cdot 16$ & 0.62 \\
\hline 500 & $\begin{array}{l}0.994 \\
1 \cdot 292 \\
1 \cdot 120\end{array}$ & $1 \cdot 135$ & $0 \cdot 15$ & 0.22 \\
\hline 700 & $\begin{array}{l}0.198 \\
0 \cdot 180 \\
0.180\end{array}$ & $0 \cdot 186$ & 0.01 & 0.04 \\
\hline \multicolumn{5}{|c|}{ Water jet cooling } \\
\hline 300 & $\begin{array}{l}2 \cdot 060 \\
2 \cdot 256 \\
1.436\end{array}$ & 1.917 & 0.43 & $0 \cdot 37$ \\
\hline 500 & $\begin{array}{l}1.210 \\
0.964 \\
1.162\end{array}$ & $1 \cdot 112$ & $0 \cdot 13$ & $0 \cdot 21$ \\
\hline 700 & $\begin{array}{l}0.240 \\
0.276 \\
0.150\end{array}$ & $0 \cdot 222$ & 0.06 & 0.04 \\
\hline
\end{tabular}

Table 9. Residual flexural strength of CC 


\begin{tabular}{|c|c|c|c|c|}
\hline Temperature: ${ }^{\circ} \mathrm{C}$ & $\begin{array}{c}f_{\mathrm{f}} \text { or } f_{\mathrm{fT}}: \\
\mathrm{MPa}\end{array}$ & $\begin{array}{c}\bar{f}_{\mathrm{f}} \text { or } \bar{f}_{\mathrm{fT}}: \\
\mathrm{MPa}\end{array}$ & $\sigma$ & $\bar{f}_{\mathrm{f} T} / \bar{f}_{\mathrm{f}}$ \\
\hline 20 & $\begin{array}{l}5 \cdot 388 \\
5 \cdot 370 \\
4 \cdot 632\end{array}$ & $5 \cdot 130$ & 0.43 & $1 \cdot 00$ \\
\hline \multicolumn{5}{|l|}{ Air cooling } \\
\hline 300 & $\begin{array}{l}4 \cdot 100 \\
4 \cdot 298 \\
5 \cdot 388\end{array}$ & $4 \cdot 199$ & $0 \cdot 14$ & 0.82 \\
\hline 500 & - & $\mathrm{H}$ & - & 0.00 \\
\hline $\begin{array}{l}700 \\
\text { Water jet cooling }\end{array}$ & - & $\mathrm{H}$ & - & - \\
\hline 300 & $\begin{array}{l}2 \cdot 844 \\
2 \cdot 814 \\
2 \cdot 130\end{array}$ & $2 \cdot 596$ & $0 \cdot 40$ & 0.51 \\
\hline 500 & - & $\mathrm{H}$ & - & 0.00 \\
\hline 700 & - & $\mathrm{H}$ & - & - \\
\hline
\end{tabular}

Table 10. Residual flexural strength of GC: H, specimen rupture during heating phase

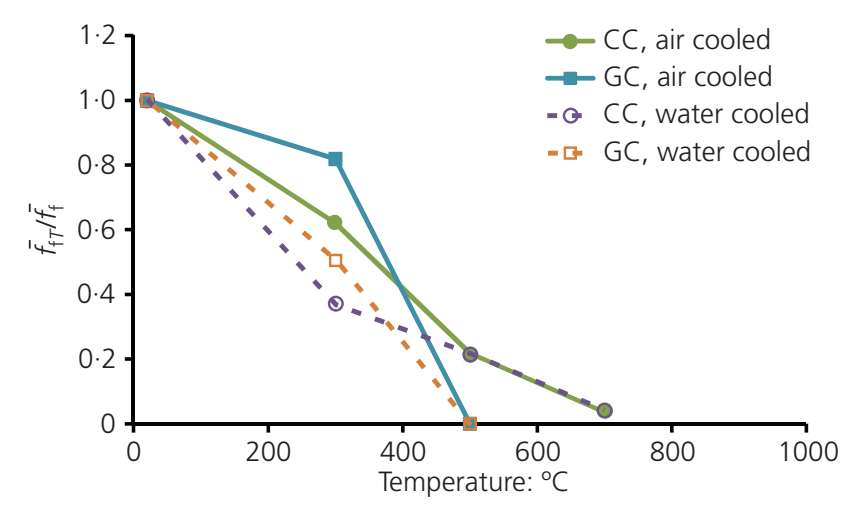

Figure 9. Residual flexural strength of CC and GC

temperature that is more pronounced above $300^{\circ} \mathrm{C}$. Again, it seems that cooling by water jets influenced this property more than cooling in air. An interesting result was registered for temperatures above $500^{\circ} \mathrm{C}$ in that $\mathrm{CC}$ presented a similar reduction in residual flexural strength independently of the cooling process. At $500^{\circ} \mathrm{C}, \mathrm{GC}$ specimens presented zero residual flexural strength while the CC specimens still had around $20 \%$ of their strength at ambient temperature.

\section{Residual modulus of elasticity}

Tables 11 and 12 and Figure 10 present the results of the residual modulus of elasticity for the concretes tested. The modulus of elasticity clearly decreased with temperature, showing a value of zero at $500^{\circ} \mathrm{C}$ for $\mathrm{GC}$ and around $10 \%$ of the reference value for CC. The concretes showed similar behaviour for temperatures up

\begin{tabular}{lrc}
\hline Temperature: ${ }^{\circ} \mathrm{C}$ & $\bar{E}_{\mathrm{c}}: \mathrm{GPa}$ & $\bar{E}_{\mathrm{CT}} / \bar{E}_{\mathrm{C}}$ \\
\hline 20 & 55.91 & 1.00 \\
Air cooling & & \\
300 & 20.13 & 0.36 \\
500 & 7.53 & 0.13 \\
700 & 4.26 & 0.08 \\
Water jet cooling & & \\
300 & 17.10 & 0.31 \\
500 & 4.55 & 0.08 \\
700 & 3.05 & 0.05
\end{tabular}

Table 11. Residual modulus of elasticity of CC

\begin{tabular}{lcc}
\hline Temperature: ${ }^{\circ} \mathrm{C}$ & $\bar{E}_{\mathrm{c}}: \mathrm{GPa}$ & $\bar{E}_{\mathrm{CT}} / \bar{E}_{\mathrm{C}}$ \\
\hline 20 & $53 \cdot 17$ & 1.00 \\
Air cooling & & \\
300 & $21 \cdot 63$ & 0.41 \\
500 & $\mathrm{H}$ & 0.00 \\
700 & $\mathrm{H}$ & - \\
Water jet cooling & & \\
300 & $16 \cdot 59$ & 0.37 \\
500 & $\mathrm{H}$ & 0.00 \\
700 & $\mathrm{H}$ & -
\end{tabular}

Table 12. Residual modulus of elasticity of GC: $\mathrm{H}$, specimen rupture during heating phase

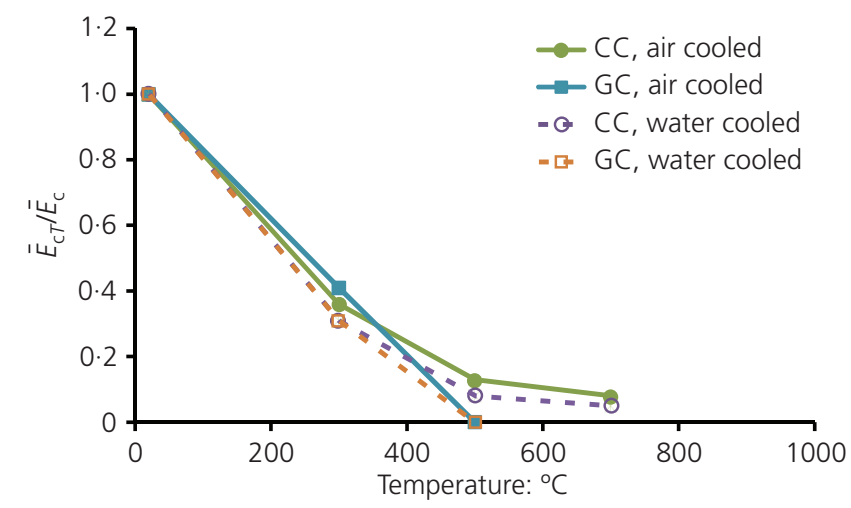

Figure 10. Residual modulus of elasticity of CC and GC

to $400^{\circ} \mathrm{C}$ for both cooling processes. Above $400^{\circ} \mathrm{C}$, however, $\mathrm{GC}$ was more affected by the heating process than was $\mathrm{CC}$. The results from these tests indicate that the cooling process does not seem to have a great influence on the residual modulus of elasticity as the values obtained for cooling in air were similar to those obtained from water cooling. 


\section{Offprint provided courtesy of www.icevirtuallibrary.com Author copy for personal use, not for distribution}

\section{Conclusions}

This paper has presented the results of research carried out to assess the residual mechanical properties (residual compressive and tensile (direct and splitting) strengths and modulus of elasticity) of ordinary calcareous aggregate concrete (CC) and granite aggregate concrete (GC) after exposure to high temperatures. Two loading levels $\left(0 \cdot 3 f_{\text {cd }}\right.$ and $\left.0 \cdot 7 f_{\text {cd }}\right)$ and two cooling processes (cooling by water jets and cooling in air) were tested. The following conclusions can be drawn from the study.

(a) The cooling process influenced the reduction of residual concrete compressive strength. For the concretes cooled using water jets, for a loading level of $0 \cdot 3 f_{\mathrm{cd}}$, CC showed a greater strength reduction than GC. For a loading level of $0 \cdot 7 f_{\text {cd }}$, both concretes suffered large decreases in residual compressive strength with increases in exposure temperature.

(b) Loading level positively influenced the residual compressive strength of the concretes for temperatures up to slightly above $300^{\circ} \mathrm{C}$ and for cooling in air because loading can limit some internal cracking in concrete. The results also showed that, the higher the loading level, the greater was the influence of the cooling process (especially for cooling by water jets) on reducing the residual compressive strength.

(c) The residual tensile strength of concretes also decreased with exposure temperature, but the cooling process had less influence on this property than on residual compressive strength. The reduction in residual tensile strength of $\mathrm{CC}$ was similar for both direct tensile and splitting tensile tests and for both cooling processes. The same is not true for $\mathrm{GC}$, in which the reduction after $300^{\circ} \mathrm{C}$ was more marked for splitting tensile strength.

(d) The residual flexural strength also decreased as a function of exposure temperature, this reduction being more pronounced in GC. Cooling by water jets had more effect on this mechanical property than air cooling.

(e) The residual modulus of elasticity showed a similar decrease with exposure temperature, independently of the type of aggregate or the cooling process used.

\section{Acknowledgements}

The authors thank SIKA S.A., Portugal, and the Portuguese Foundation for Science and Technology (FCT) for their financial support in this experimental research.

\section{REFERENCES}

Abrams M (1971) Compressive Strength of Concrete at Temperatures to $1600 \mathrm{deg}$ F. American Concrete Institute, Detroit, MI, USA, ACI SP-25, pp. 33-58.

Abrams MS (1983) Fire Safety of Concrete Structures. American Concrete Institute, Detroit, MI, USA, ACI SP-80, 308 pp.

Aitcin PC (2003) The durability characteristics of high performance concrete: a review. Cement and Concrete Composites 25(4-5): 409-420.

Bazant ZP and Kaplan MF (1996) Concrete at High
Temperatures: Material Properties and Mathematical Models. Longman, London, UK

Castellote M, Cruz A, Carmen A, Xavier T and Javier C (2004) Composition and microstructural changes of cement pastes upon heating, as studied by neutron diffraction. Cement and Concrete Research 34(9): 1633-1644.

CEN (Comité Européen de Normalisation) (2003) EN 12390-6: Testing hardened concrete. Part 6: Tensile splitting strength of test specimens. CEN, Brussels, Belgium.

CEN (Comité Européen de Normalisation) (2009) EN 12390-5: Testing hardened concrete. Part 5: Flexural strength of test specimens. CEN, Brussels, Belgium.

Chan YN, Peng GF and Anson M (1999) Residual strength and pore structure of high-strength concrete and normal strength concrete after exposure to high temperatures. Cement and Concrete Composites 21(1): 23-27.

Diederichs U, Jumpannen U and Schneider U (1995) High temperature properties and spalling behavior of high strength concrete. Proceedings of 4th Weimar Workshop on High Performance Concrete: Material Properties and Design, Weimar, Germany. Technical University of Rostock, Rostock, Germany, pp. 219-236.

Georgali B and Tsakiridis PE (2005) Microstructure of firedamaged concrete. A case study. Cement and Concrete Composites 27(2): 255-259.

Hager I (2004) Comportement à Haute Température des Bétons à Haute Performance - Evolution des Principales Propriétés Mécaniques. Doctoral thesis, École Nationale des Ponts et Chaussées, Paris, France.

Harmathy TZ (1970) Thermal properties of concrete at elevated temperatures. ASTM Journal of Materials 5(1): 47-74.

Harmathy TZ (1995) Properties of building materials. The SFPE Handbook of Fire Protection Engineering, 2nd edn. Society of Fire Protection Engineers, Boston, MA, USA, pp. 142155.

Hertz KD (2003) Limits of spalling of fire-exposed concrete. Fire Safety Journal 38(2): 103-116.

Hertz KD (2005) Concrete strength for fire safety design. Magazine of Concrete Research 57(8): 445-453.

Husem M (2006) The effects of high temperature on compressive and flexural strengths of ordinary and high-performance concrete. Fire Safety Journal 41(2): 155-163.

Janotka I and Nurnbergerova T (2005) Effect of temperature on structural quality of the cement paste and high-strength concrete with silica fume. Nuclear Engineering and Design 235(17-19): 2019-2032.

Khoury GA (1992) Compressive strength of concrete at high temperatures: a reassessment. Magazine of Concrete Research 44(16): 291-309.

Kodur VR and Harmathy TZ (2002) Properties of building materials. In The SFPE Handbook of Fire Protection Engineering, 3rd edn (DiNenno PJ (ed.)). National Fire Protection Association, Quincy, MA, USA, pp. 1.155-1.181.

Kodur VKR and Sultan MA (1998) Structural behavior of high strength concrete columns exposed to fire. Proceedings of an 
International Symposium on High Performance and Reactive Power Concrete, Sherbrooke, Quebec, Canada, pp. 217-232.

Noumowé AN (1995) Effet des Hautes Températures $\left(20-600^{\circ} \mathrm{C}\right)$ sur le Béton. Cas Particulier du Béton à Hautes

Performances. Doctoral thesis, Institute National des Sciences Appliqués de Lyon, Lyon, France.

Phan LT and Carino NJ (1998) Review of mechanical properties of HSC at elevated temperature. Journal of Materials in Civil Engineering, ASCE 10(1): 58-64.

Pimienta P (1998) Caractérisation de 6 Bétons d'étude en Traction Directe. CSTB, Paris, France, final report.

Pimienta P (1999) Évolution des Caractéristiques des BHP Soumis à des Températures Élevées (Tranche 1), Résistances en Compression et Modules d'élasticité. CSTB, Paris, France, final report.

Poon C-S, Azhar S, Anson M and Wong Y-L (2001) Strength and durability recovery of fire-damaged concrete after post fire curing. Cement and Concrete Research 31(9): 1307-1318.

RILEM TC 129-MHT (2004) Test methods for mechanical properties of concrete at high temperatures. Materials and Structures 37(266): 139-144.

RILEM TC 200-HTC (2005) Mechanical concrete properties at high temperature - modelling and applications. Materials and Structures 38(284): 913-919.

Sakr K and El-Hakim E (2005) Effect of high temperature or fire on heavy weight concrete properties. Cement and Concrete Research 35(3): 590-596.

Santos CC, Rodrigues JPC and Coelho AL (2009) Influence of the cooling process on the residual mechanical properties of ordinary concretes. Proceedings of the 1st International Workshop on Concrete Spalling Due to Fire Exposure, Leipzig, Germany, 201-210.

Schneider U (1988) Concrete at high temperatures - a general review. Fire Safety Journal 13(1): 55-68.

Schneider U (1992) Behaviour of Concrete at High Temperatures. Beuth Verlag, Berlin, Germany.

Schneider U and Nãgele E (1989) Reparability of Fire Damaged Structures. CIB, Gesamtuochschule Kassel, Germany, Report W14, publication n. 111.

Sims I and Brown B (1998) Concrete aggregates. In Lea's Chemistry of Cement and Concrete, 4th edn. Arnold, London, UK, pp. 903-1011.

Thelandersson S (1971) Effect of High Temperatures on Tensile Strength of Concrete. Lund Institute of Technology, Lund, Sweden, Bulletin 26.

Xiao J and Konig G (2003) Study on concrete at high temperature in China - an overview. Fire Safety Journal 39(1): 89-103.

Ye G, Liu X, De Schutter G, Taerwe L and Vandevelde P (2007) Phase distribution and microstructural changes of selfcompacting cement paste at elevated temperature. Cement and Concrete Research 37(6): 978-987.

\section{WHAT DO YOU THINK?}

To discuss this paper, please submit up to 500 words to the editor at journals@ice.org.uk. Your contribution will be forwarded to the author(s) for a reply and, if considered appropriate by the editorial panel, will be published as a discussion in a future issue of the journal. 